\title{
Emotions, Oral Arguments, and Supreme Court Decision Making
}

\author{
Ryan C. Black Michigan State University \\ Sarah A. Treul University of North Carolina at Chapel Hill \\ Timothy R. Johnson University of Minnesota \\ Jerry Goldman Chicago-Kent College of Law
}

\begin{abstract}
Students of linguistics and psychology demonstrate that word choices people make convey information about their emotions and thereby their intentions. Focusing on theory from these related fields we test whether the emotional content of Supreme Court justices' questions and comments made during oral arguments allow us to predict the decisions they make. Using aggregate data from all arguments between 1979 and 2008 and individual-level data from 2004 through 2008 we find justices' use of more unpleasant language towards the attorney representing one side of a case reduces the probability that side will prevail on the merits, both in terms of individual justices' votes and the overall case outcome.
\end{abstract}

L hroughout David Friedman's argument in McCreary v. ACLU (2005) Justice Antonin Scalia made it abundantly clear he disagreed with the position that displaying the Ten Commandments in public schools and courthouses violates the Establishment Clause of the First Amendment. Admonishing Friedman in an exchange about the meaning of such displays Scalia noted, "I don't think they're really saying that the particular commandments of the Ten Commandments are the basis of the Declaration of Independence. That's idiotic." Later he used the same harsh language: "If that's what it means, it's idiotic. I don't think anybody is going to interpret it that way. You can't get the Declaration of Independence out of the Ten Commandments." ${ }^{1}$ In posing these "questions" to Friedman, Scalia seemed to indicate his clear belief that the First Amendment does not prohibit the public display of the Ten Commandments in either public schools or courthouses. Unsurprisingly, when the case was decided, Scalia dissented from the majority's holding that the public displays violated the Establishment Clause.

Is Justice Scalia's emotionally charged behavior and word choice in McCreary an anomaly or is it indicative of a more systematic pattern of behavior exhibited by him and his colleagues? In other words, do justices telegraph or otherwise preview their preferences over the legal and policy outcomes of cases when they ask questions or make comments to attorneys who appear before them during oral arguments? To answer this question we draw insights from psychology, linguistics, and political science and utilize the Dictionary of Affect in Language (Whissell 1989; Whissell et al. 1986) to analyze whether the emotional content of justices' questions during these proceedings can be used to predict how they will decide on the merits.

Specifically, we examine a unique corpus of more than 8 million words spoken by the justices during oral arguments over the past 30 years. Our results suggest that when the justices focus more unpleasant language toward one attorney, the side he represents is more likely to lose. The same relationship holds between an individual justice's questioning patterns and her final vote on the merits. In what follows we cross disciplines to develop a theoretically-informed argument that links emotions and behavior, we describe our data and measurement strategy to test this account, and finally, we discuss the implications of our findings.

Our findings make several contributions. First, we extend to Supreme Court justices the burgeoning

\footnotetext{
${ }^{1}$ To hear arguments in this case, navigate to http://oyez.org/cases/2000-2009/2004/2004_03_1693/argument. This specific exchange between Scalia and Freedman occurs between 38:36 and 39:51 in the audio file.
}

The Journal of Politics, Vol. 73, No. 2, April 2011, Pp. 572-581

doi:10.1017/S002238161100003X

(C) Southern Political Science Association, 2011

ISSN 0022-3816 
focus on how the linguistic nature of language used by political actors-presidents (Sigelman and Whissell 2002a, 2002b) and members of Congress (Sigelman, Deering, and Loomis 2000; Monroe, Colaresi, and Quinn 2009)—affects decisions they make. Second, we add to the mounting evidence that scholars must understand the entire decision-making process in order to have the most accurate picture of how actors decide. In particular, we add to the literature that demonstrates justices' behavior during the oral argument phase of this process plays a key role in signaling the decisions they will ultimately make (Johnson, Wahlbeck, and Spriggs 2006). Third, we speak to the debate concerning how justices' preferences over case outcomes affect their decisions. While we do not find a strong ideological connection, we do find justices reveal, in an emotional manner during oral arguments, how they may vote. Thus, as scholars continue to build models of the Court's decision-making process they must account for what transpires during these proceedings, including the justices' emotional state as they move toward decisions. In short, our results indicate we must rethink the models that now dominate our subfield.

\section{Decision Making and Emotion in Language}

When Mayhew (1974) published his famous work on Congress he noted that members stake out policy positions when they speak publicly about a particular law or issue. The more general idea-that political actors convey information about their views when they speak-is an accepted view in political science and economics (e.g., Austen-Smith 1990; Diermeier and Fedderson 2000). While words themselves have meaning, we are more interested in what people mean beyond the literal interpretation of what they say (Pennebaker, Mehl, and Niederhoffer 2003). As Hart explains, "Words... are not important in and of themselves. They are important because they point to a speaker's feelings and to the situations in which they find themselves" $(2001,44)$. This intuition stems from research that ties emotion expressed through language to people's feelings, intentions, and psychological thinking (Lacan 1968; Tausczik and Pennebaker 2009). ${ }^{2}$

The claim that words carry emotional content is neither new nor controversial among decision-

${ }^{2}$ Even words that do not directly describe emotions are capable of communicating a clear affective tendency (Petrone and Whissell 1988). making scholars (see, e.g., Bagozzi et al. 2000; Frijda 1986; Hart 2001; Pennebaker, Mehl, and Niederhoffer 2003; Pieters and Van Raaij 1988). In fact, social psychologists find that when an individual desires a particular outcome, emotions can be used to predict the individual's behavior (Ajzen 1985, 1996; Ajzen and Fishbein 1980; Fishbein and Ajzen 1975). Additionally, individuals use emotions with the greatest frequency when they are concerned about an outcome from a decision-making process (Zeelenberg et al. 2008). This scholarship provides the theoretical link that connects emotions to behavior through the words people (in this case political actors) use.

Our point is that if there is an emotional element to language a political actor uses, and if the political actor has a preference over an outcome, then the actor's emotions can help analysts predict what decision she will make. Zeelenberg and his colleagues $(2008,19)$ explain this relationship: "We propose that emotions commit decision makers to certain courses of action by providing control precedence (Frijda, 1986) which means that the experience of an emotion brings forward an associated goal that may overrule other goals..." Justice Scalia's word choice ("idiotic"), and subsequent vote in McCreary, is case in point; his unpleasant language towards the ACLU attorney indicated he would cast a vote consistent with his language.

Linguists (Whissell et al. 1986), sociolinguists (Eckert 1999), discourse analysts (Schiffrin 1994), and communications scholars (Robinson and Giles 2001) reach similar conclusions. They demonstrate words, and the emotions behind them, provide valuable insight into people's intentions, motives, and desires. In turn, Zeelenberg et al. conclude, "... emotions can be understood as programs for intuitive decision-making, imposing upon the decision maker inclinations for action that, in a given situation, most adequately serve current strivings" $(2008,24)$. Ultimately, understanding emotions is important (Pennebaker, Mehl, and Niederhoffer 2003); by systematically analyzing people's words-and thus their desires and intentions - it is possible to predict their actions (Zeelenberg et al. 2008).

\section{The Role of Oral Arguments in Supreme Court Decision Making}

Based on the multidisciplinary findings in the previous section, we posit there is an emotional component of language that may help us understand a speaker's view of a particular topic. Recognizing this, we turn to U.S. 
Supreme Court oral arguments to gain insight into how the language justices invoke during these proceedings may allow us to predict individual votes and aggregate case outcomes. We first place our study within existing works.

Oral arguments are an important component in the Supreme Court's decision-making process. In particular, they provide justices with information and offer a "fresh perspective" when deciding cases (O'Brien 2008, 246; cf. Segal and Spaeth 2002, 280). On this account, oral arguments influence case outcomes because they give justices an opportunity to clear up lingering questions from the briefs and to gauge their colleagues' views (Johnson 2004; Wasby, D'Amato, and Metrailer 1976). Research also demonstrates the quality of arguments influences justices' decisions (Johnson, Wahlbeck, and Spriggs 2006; McGuire and McAtee 2007).

A growing body of evidence also suggests oral arguments may provide a barometer of how justices will rule in a given case. For example, Chief Justice John Roberts has suggested that the number of questions asked during oral arguments can be used to predict case outcomes. Before joining the Court, Roberts tested this hypothesis by tallying the number of questions asked of advocates in a small number of arguments. Across a sample of 28 cases selected from two terms, he found that $86 \%$ of the time the party receiving the most inquires from the bench ultimately lost the case (Roberts 2005). ${ }^{3}$

Court watchers extend the Chief Justice's findings. Greenhouse proposes it may be possible to predict the outcome of cases because the "tenor of the argument" often reveals justices' intentions (2008a, 14). For instance, when the Court heard oral arguments in Crawford v. Marion County Election Board (2008), she speculated the justices' "questioning indicated that a majority did not accept the challenger's basic argument-that voter-impersonation fraud is not a problem" (Greenhouse 2008b, 1). For Greenhouse, the justices' behavior also meant they wanted to dismiss the case. Additionally, she pointed out that Justice Scalia spoke "with evident disapproval" during his questioning. Ultimately, Greenhouse suggests the tone of oral argument questions can be used to predict outcomes-or at least some justices' votes.

Evidence across cases, justices, and time supports these anecdotes. In her response to the Supreme

${ }^{3}$ Results from Roberts' small-n study have been verified using more comprehensive data sets. See, for example, Johnson et al. (2009) and Epstein et al. (forthcoming).
Court Forecasting Project (Martin et al. 2004) Greenhouse reexamined her oral argument stories from the 2002 term and reviewed her predictions in 16 cases (Greenhouse 2004). ${ }^{4}$ What she found was not a surprise to her but may have been to the other participants in the project. Indeed, Greenhouse predicted the outcomes of more cases and votes of individual justices, based on her assessment of questions asked during arguments, than either side of the forecasting project. She attributes her advantage over the computer based or expertise approach to the fact that hers were "postargument predictions" (2004, 782).

Two additional studies extend these analyses and further hint at a role for the emotional content of justices' questions. Analyzing a sample of 10 cases from the Court's 2002 term, Shullman (2004) finds initial evidence to suggest that justices' language may be related to Court decisions. Having coded whether the justices' questions were either helpful or hostile in nature, Shullman notes that, " $[\mathrm{M}]$ any of the justices pose hostile or argumentative questions to both sides, but it seems that more often they go easy on the lawyer for the party they support and only play devil's advocate to the lawyer for the party they oppose" (2004, 292-93). Wrightsman (2008) uses a different coding scheme and a sample of 24 cases to reach a similar conclusion.

We draw two lessons from the literature in these two sections. First, the emotional content of language may allow us to predict behavior by understanding actors' motives, intentions, and desires. Second, limited evidence demonstrates the emotional content of justices' language at oral arguments may help scholars predict how they will vote. These lessons lead us to hypothesize that: When the Court directs more hostile (pleasant) language towards a particular side's attorney, the Court is less (more) likely to rule in favor of that side.

\section{Data and Measurement}

To test this hypothesis we conduct two related analyses. First, we extend the approach used by Greenhouse and others to analyze outcomes in all

\footnotetext{
${ }^{4}$ The Supreme Court Forecasting Project pitted legal experts against political scientists in a friendly interdisciplinary competition. The goal was to accurately predict the outcome of each argued case on the Supreme Court's 2002 docket. The Project compares the relative accuracy of two different methods of prediction (computer generated predictions and expert predictions).
} 
orally argued cases from 1979 to $2008 .^{5}$ Second, because emotion in language is an individual level phenomenon, we analyze voting behavior at the justice level from 2004 to $2008 .^{6}$ We code our caselevel dependent variable 1 if the petitioner wins and 0 if the respondent wins. Similarly, at the justice level we code our dependent variable 1 if a justice votes to reverse the lower court decision and 0 if a justice votes to affirm. Both of these variables come from the Supreme Court Database. ${ }^{7}$

To operationalize our emotion-based independent variables we begin by compiling the oral argument transcripts for all cases decided during our 30-term sample. ${ }^{8}$ The aggregate data include 2996 cases, more than 335,000 justice utterances, ${ }^{9}$ and a corpus of nearly 8.4 million words. The individual-level data, spanning the 2004-2008 terms, include roughly 43,000 justice

${ }^{5}$ Electronic transcripts of oral arguments are unavailable prior to the Court's 1979 term. While microfiche transcripts are generally available from 1969 to 1978 , their image quality is poor, which makes their digitization-a necessary step for our content analysis - unreliable. Note that we excluded orally argued cases that resulted in an equally divided court, those where the Court voted to dismiss the case for want of jurisdiction, and those coming to the Court through its original (as opposed to appellate) jurisdiction. We also omitted the small number of cases where the Court asked that a case be reargued. Finally, we dropped several cases due to missing values in the lower court ideology variable or the party codes used to create the control variables described below. Despite these various omissions, we note the cases used in our analysis are generalizable to more than $95 \%$ of the cases heard by the Court.

${ }^{6}$ The Court only began providing justice-identified transcripts in the 2004 term.

${ }^{7}$ We used 2009 Release 04 for the case and justice-level variables described herein. These files are available at http://scdb.wustl. edu/data.php?s $=2$.

${ }^{8}$ We obtained all of our transcripts from LexisNexis. In building our dataset, we discovered that Lexis' coverage for the first three terms omitted 51 transcripts. We have thoroughly investigated these missing cases and ultimately have little reason to believe their omission undermines our analysis. Please see the online supplement for details regarding this secondary analysis.

${ }^{9}$ By utterance we mean each time a justice speaks during the arguments. In the transcripts, the marker "QUESTION," regardless of whether the justice asks a question or makes a statement, precedes each speaking turn. Because we code every question and statement, we simply label each of them utterances. Sometimes, however, these utterances have little to do with the law or policy surrounding the case at hand. For instance, during the 2006 term, Justice Breyer offered this gem: "Sorry, I have laryngitis. Can you hear me all right?" (The case in question, Hudson v. Michigan, is available on Lexis at 2006 U.S. Trans Lexis 47). Our argument, of course, is that these nonsubstantive statements and questions made by the justices simply constitute random noise in our data. utterances and approximately 1.4 million words spread across 3,042 votes cast in 347 cases. $^{10}$

Transcripts in hand, we employ the Dictionary of Affect in Language (hereafter DAL) (Whissell 1989; Whissell et al. 1986) to gauge the emotional content of the justices' words. Whissell (1989) argues that emotion in language can be described adequately and efficiently in terms of a two-dimensional space defined by the pleasantness and activation of words (see also Plutchik 1994; Russell 1978). She measures each dimension on a 3-point scale; words are unpleasant, neutral, or pleasant as well as passive, neutral, or active. This continuum allows scholars to determine the overall emotive nature of words. ${ }^{11}$ Very unpleasant words are defined as those words in the $10^{\text {th }}$ percentile (or lower) of pleasantness; some representative examples include chaos, failed, hostile, nightmare, and phony. By contrast, very pleasant words are defined as those words in the $90^{\text {th }}$ percentile (or higher) of pleasantness; examples include award, confidence, favorable, quality, and respect. More generally, with the Dictionary "one could arrive at a description of the affective tone of the entire list or passage" (Whissell et al. 1986). This is clearly evident in the language (e.g., "idiotic") used by Scalia in McCreary, which contains a number of words that are scored as being unpleasant by the DAL.

The DAL includes a total list of 8,743 words, of which $11 \%$ are coded as very unpleasant and $10 \%$ are coded as very pleasant. It is "an accurate description of English word-usage patterns" (Whissell 1999) and has proven a highly reliable and valid way to capture affect in language (Dubois 1997; Sigelman and Whissell 2002a). Additionally, it provides an objective and replicable measure of the emotional content of language. ${ }^{12}$

\footnotetext{
${ }^{10}$ During much of the Court's 2004 term, Chief Justice William H. Rehnquist was absent from oral arguments due to treatment for thyroid cancer but still participated in and cast votes in these cases. As we lack oral argument data for Rehnquist in these observations, we exclude his votes in these cases from our analysis.
}

${ }^{11}$ Data for the DAL were collected in the latter half of the 1990s. Over 200 volunteers rated words on each of the scales to generate the rating judgments that were used to create the DAL. For a more detailed description of the process, please see the online supplement. We note that the types of words we use in this analysisvery unpleasant and very pleasant words-are only scored on the pleasantness continuum. Adding activation would allow us to measure "cheerful" or "nasty" words, but we believe pleasant and unpleasant words most directly tap into a speaker's emotions, which is our latent concept of interest. The online supplement provides a figure that plots a sample of words from the DAL on both the two dimensions of pleasantness and activation.

${ }^{12}$ Whissell (2001) suggests one main limitation to her Dictionary. Specifically, the scores are created in a context free way. That is, words are scored individually and not within the passage where they are used. Thus, the DAL is insensitive to complexities in word choice like humor, irony, and sarcasm. 
Using the DAL we analyze the content of justices' questions and statements during oral argument by counting the total number of very pleasant and very unpleasant words aimed at each attorney. We then divide this number by the total number of words directed at each side, which gives us the proportion of very (un)pleasant words from the bench. Finally, because we are interested in the relative level of emotion directed to a particular side, we subtract the percentage for the respondent's side from the percentage for the petitioner's side to generate our two variables of interest: Percent More Unpleasant Words Directed at Petitioner and Percent More Pleasant Words Directed at Petitioner. ${ }^{13}$ Positive values indicate more unpleasant or pleasant words used in the give-and-take with the petitioner. We therefore expect the variables' coefficients to be negative for unpleasant words and positive for pleasant words.

Because of the finding that the simple number of questions is related to a side's likelihood of winning (e.g., Roberts 2005), we also control for Number More Questions Directed at Petitioner, which is the difference between the number of questions asked of the petitioner and respondent. Again, positive numbers indicate more intense questioning of the petitioner, and so we expect a negative sign on this variable.

Beyond our variables of interest, we control for a variety of alternative explanations that may influence case and vote outcomes. First, while justices' questions may indicate how they view the present case, we need to control for their more general ideological predilections. ${ }^{14}$ To capture the overall effect of ideology on the decision-making process we include three variables. In the case-level model Political Ideology measures the ideology of the median justice on the Court as computed by Martin and Quinn (2002). In the justice level model Political Ideology is coded as a justice's ideal point estimate (Martin and Quinn 2002). For both models we include Lower Court Decision Was Conservative, which is coded 1 if the decision of the court being reviewed was ideologically conservative in nature and 0 if it was liberal. Finally, we include Ideology $\boldsymbol{x}$ Lower Conservative, which is

\footnotetext{
${ }^{13}$ The online supplement contains descriptive data that shows the degree to which each justice in our individual-level model uses pleasant and unpleasant language, as well as the difference between how much of each type of language they use towards petitioners versus respondents.

${ }^{14}$ One potential concern is that our emotions variables are simply a proxy for the Court's (or a justice's) ideological agreement with a given side. We have explored this hypothesis extensively by estimating auxiliary models and ultimately find little evidence to support the underlying argument. See the online supplement for additional details.
}

the interaction between our political ideology and lower court variable. Taken together, these variables allow us to assess whether the Court (or a justice) is more likely to reverse when the lower court's decision stands in ideological opposition to the preferences of the Court (or to a justice in the individual level model).

When the Solicitor General (SG) participates in a case as amicus curiae the side the SG supports is significantly more likely to win (Segal 1988). To control for the benefit litigants may get from the federal government's support we include two variables: Solicitor General as Amicus Supports Petitioner and Solicitor General as Amicus Supports Respondent. The first is coded 1 if the federal government supports the petitioner and 0 otherwise. The second is coded similarly if the government supports the respondent or not.

Additionally, litigants are more likely to win at the Supreme Court when they garner support from interest groups (Collins 2004, 2008; Songer and Sheehan 1993). Thus, we also include two variables to account for this support: Number of Amicus Briefs Supporting Petitioner and Number of Amicus Briefs Supporting Respondent. These variables are the number of briefs filed on behalf of the petitioner or respondent, respectively. The former should be positively related with the petitioner's success while the latter should be negatively related.

Finally, we include Petitioner's Level of Resources and Respondent's Level of Resources, which measure litigant status. Like Collins $(2004,2008)$ we use the Supreme Court database party codes to determine which status category each party fell into: poor individuals, minorities, individuals, unions or interest groups, small businesses, businesses, corporations, local governments, state governments, and the U.S. government. The weakest category-poor individuals-is coded " 1 " whereas the strong category-the U.S. government-is coded " 10 ."15

\section{Results}

Table 1 displays the parameter estimates for our model. Both models do a good job of predicting the correct outcome and each achieves a reasonable reduction in errors made by guessing the modal outcome (i.e., reverse). Taken together, these results

\footnotetext{
${ }^{15}$ We use Collins' scale over other scales such as the Sheehan, Mishler, and Songer(1992) approach owing to Collins' careful inclusion of interest groups.
} 
Table 1 Logistic Regression Models Predicting Case and Vote Outcomes

\begin{tabular}{|c|c|c|}
\hline & $\begin{array}{l}\text { Court Outcome } \\
(1979-2008)\end{array}$ & $\begin{array}{c}\text { Justice Votes } \\
(2004-2008)\end{array}$ \\
\hline Percent More Unpleasant Words Directed at Petitioner & $-0.105^{\star}(0.037)$ & $-0.032^{\star}(0.013)$ \\
\hline Percent More Pleasant Words Directed at Petitioner & $0.081 \quad(0.042)$ & $-0.011 \quad(0.014)$ \\
\hline Number More Questions Directed at Petitioner & $-0.021^{\star}(0.002)$ & $-0.061^{\star}(0.007)$ \\
\hline Political Ideology & $-0.334 \quad(0.203)$ & $0.276^{\star}(0.039)$ \\
\hline Lower Court Decision Was Conservative & $0.310 \quad(0.201)$ & $1.018^{\star}(0.243)$ \\
\hline Political Ideology x Lower Court Conservative & $-0.321 \quad(0.300)$ & $-0.531^{\star}(0.052)$ \\
\hline Solicitor General as Amicus Supporting Petitioner & $0.737^{\star}(0.124)$ & $1.079^{\star}(0.268)$ \\
\hline Solicitor General as Amicus Supporting Respondent & $-0.891^{\star}(0.149)$ & $-0.663^{\star}(0.255)$ \\
\hline Number of Amicus Briefs Supporting Petitioner & $0.080^{\star}(0.019)$ & $0.054^{\star}(0.023)$ \\
\hline Number of Amicus Briefs Supporting Respondent & $-0.084^{\star}(0.019)$ & $-0.038^{\star}(0.016)$ \\
\hline Petitioner's Level of Resources & $0.091^{*}(0.019)$ & $0.078 \quad(0.043)$ \\
\hline Respondent's Level of Resources & $-0.067^{\star}(0.018)$ & $-0.113^{\star}(0.043)$ \\
\hline Constant & $0.483^{*}(0.241)$ & $0.240 \quad(0.478)$ \\
\hline Observations & 2996 & 3042 \\
\hline Log Likelihood & -1765.667 & -1673.836 \\
\hline Psuedo R2 & 0.107 & 0.161 \\
\hline Percent Correctly Predicted & 68.7 & 72.7 \\
\hline Proportional Reduction in Error & 15.7 & 24.8 \\
\hline
\end{tabular}

${ }^{*}$ denotes $\mathrm{p}<0.05$ (two-tailed test).

Note: Robust standard errors are reported in parentheses next to maximum-likelihood parameter estimates. Standard errors for the Justice Votes model are clustered on each unique case $(\mathrm{N}=347)$. Political Ideology (and its part in the interaction term) for the Court Outcome model is the median justice's ideal point estimate. Political Ideology (and its part in the interaction term) for the Justice Vote model is the voting justice's ideal point estimate.

provide ample support for our main hypothesis. At both the case and justice level we find a negative and statistically significant effect for our unpleasant words variable. ${ }^{16}$ This means that as the Court (or an individual justice) directs more negative language towards the petitioner we find that the likelihood of the petitioner's winning decreases. This result holds even as we control for accepted alternative explanations for why the justices decide for one side over the other.

The substantive effects of the unpleasant words variable, which we portray in Figure 1, are strong. The left panel presents results from the aggregate analysis, where the outcome of interest is whether the petitioner wins on the merits. On the $\mathrm{x}$-axis we display the extent to which the Court directs more unpleasant language at the petitioner versus the respondent. Negative values on the far left indicate more unpleasant language used towards the respondent and positive values on the far right indicate more unpleasant language used toward the petitioner.

\footnotetext{
${ }^{16}$ To ensure that a single justice is not driving our key results, we estimated a series of additional models at both the case outcome and justice vote level. While we provide additional details in the online supplement, we ultimately conclude that our results are generalizable and not unduly influenced by a single justice.
}

When the Court's unpleasantness is at the sample average of 0 (i.e., balanced treatment for the petitioner and respondent), the petitioner's likelihood of winning is $0.61[0.58,0.64]$, which is roughly equivalent with the Court's normal rate of reversal. However, when the Court directs significantly more unpleasant language towards the respondent, this probability increases by $23 \%$ to 0.75 [0.65, 0.82]. Similarly, when the Court is especially harsh towards the petitioner the likelihood of reversal drops to an anemic $0.48[0.38,0.58]$-a relative decrease of $21 \%$ that is statistically significant at the $95 \%$ level.

The individual-level results, displayed in the right panel of Figure 1, follow a similar pattern. A justice who uses $20 \%$ more unpleasant words towards the respondent has a $0.70[0.55,0.81]$ probability of voting for the petitioner while a justice who is the harshest towards the petitioner has only a 0.41 [0.30, $0.54]$ probability of voting for the petitioner.

We find mixed support for our pleasant words variable. Across the 30 terms worth of cases contained in our aggregate analysis, we find a positive and statistically robust $(\mathrm{p}=0.054)$ relationship between the relative amount of positive words directed at the petitioner and her likelihood of winning on the 


\section{Figure 1 Predicted Effect of Unpleasant Language on Court and Justice Vote Outcomes}
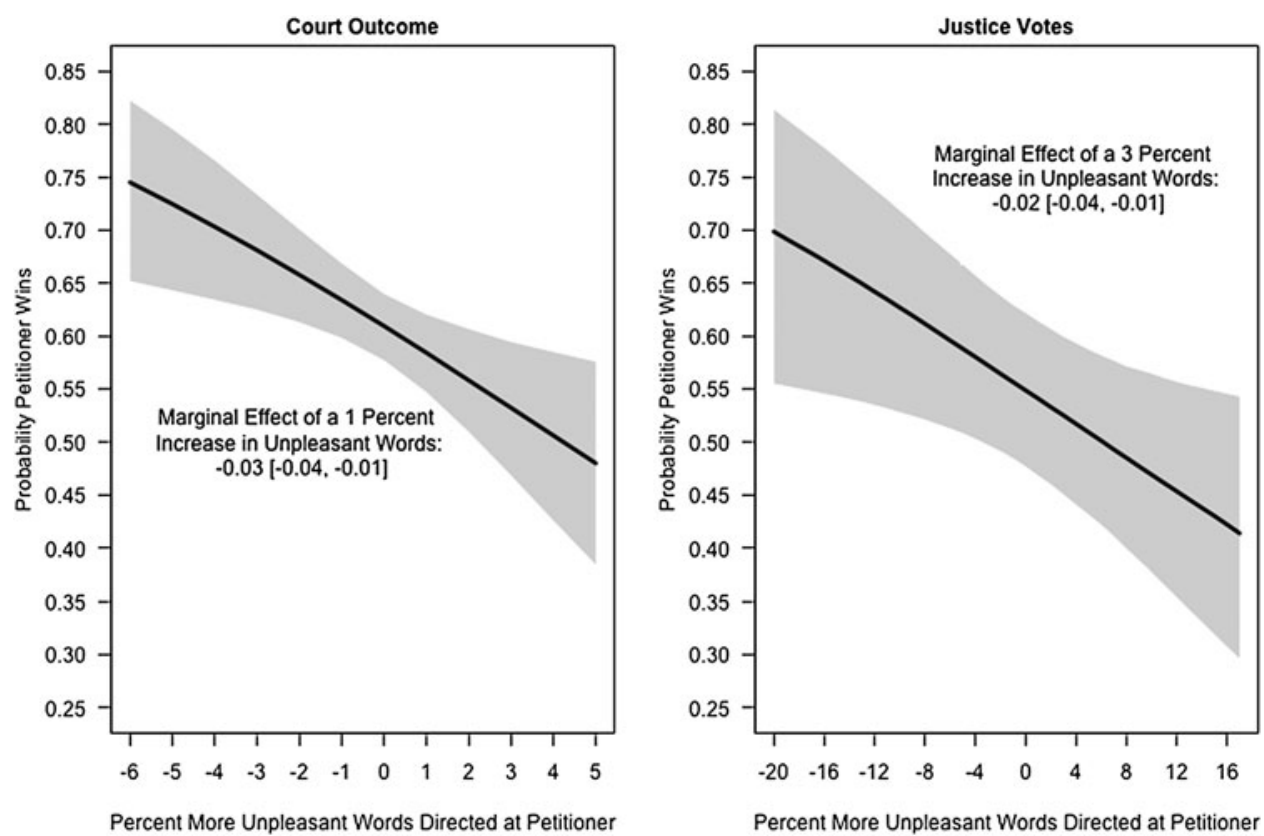

Note: The left panel represents the Court outcome dependent variable, where a 1 percent increases is slightly less than one standard deviation ( 1 S.D. $=1.11$ percent $)$. The right panel represents the justice vote dependent variable, where a 3 percent increase is the same as one standard deviation. Both marginal effects are calculated using the sample mean (i.e., 0 percent) as the baseline value. All other variables were held at their sample means or modes as appropriate. Shaded regions represent the 95 percent confidence interval obtained through stochastic simulations.

merits. The substantive magnitude of this variable is notable as well. Holding all other variables at their sample means or modes, we estimate that a $1 \%$ increase in the amount of pleasant language directed at the petitioner yields a $0.02[0.00,0.04]$ increase in the probability that the petitioner prevails in a case.

For the cases in our justice-level analysis, however, we fail to find any such relationship $(\mathrm{p}=0.42)$. While it is unclear why we fail to reject the null hypothesis on this variable, two (albeit ex post) explanations are tenable. First, the small number of utterances for each justice over four terms may not provide us enough statistical power to discover a relationship between this variable and votes. Second, since the individual-level analysis is confined to the five most recent terms, the predictive value of pleasant language may be time-bound. Additional analysis on this point, which we detail in our online supplement, suggests there might be merit to this argument. While these explanations are not entirely satisfying, due to the lack of additional justice-level data, we are limited in our ability to resolve this discrepancy.

Beyond the effect of emotions in our models, we find some Court-level evidence consistent with the existence of interplay between the preferences of the median justice and the ideological direction of the lower court decision. ${ }^{17}$ When the median justice is the most liberal we estimate a 0.73 [0.66, 0.78] probability the Court will reverse a conservative lower court decision but only a $0.66[0.59,0.72]$ probability of reversing a liberal lower court decision. ${ }^{18}$ By contrast, when the median justice is conservative, we fail to find evidence the Court differentially reverses lower court decisions based on their ideological direction $(\mathrm{p}=0.54)$.

At the justice level, however, we find stronger results. The most liberal justice has a $0.35[0.28,0.44]$ predicted probability of voting to reverse a liberal lower court decision while the same justice has a 0.85 $[0.79,0.90]$ predicted probability of voting to reverse a conservative decision. The most conservative justice,

\footnotetext{
${ }^{17}$ Statistical significance of the interaction term in the table is not a necessary condition for the existence of a meaningful interactive effect (see, e.g., Berry, DeMeritt, and Esarey 2010). To determine whether a significant effect exists, we must conduct additional postestimation calculations, which we perform using the same stochastic simulations used to generate the predicted values in Figure 1.

${ }^{18}$ The p-value for the difference in probability between a liberal and conservative lower court decision for the most liberal median justice is 0.06 .
} 
by contrast, votes to reverse a liberal and conservative lower court decision with probabilities of 0.79 [0.70, $0.85]$ and $0.50[0.40,0.60]$, respectively. ${ }^{19}$

\section{Discussion}

The highly unpleasant language ("that's idiotic" and "it's idiotic") Justice Scalia used in McCreary, and his eventual decision, does not seem to be an anomaly. Rather, his behavior parallels aggregate Court behavior across more almost 3000 cases over a 30-year time span and individual colleague's behavior over five recent terms. Indeed, our findings indicate that when justices use unpleasant language during oral arguments the side that incurs a greater proportion of harsh language is more likely to lose its case. More specifically, by taking advantage of Whissell's Dictionary of Affect in Language we provide strong evidence that the affective component of justices' language can be used to predict their votes at the merit stage. This, itself, is an important finding because it corroborates anecdotal evidence, allows practitioners another means to evaluate whether they may win or lose their case, and demonstrates that even our nation's highest jurists are not immune from the influence of emotion on decisions they make.

Beyond the practical implications of our findings, they contribute to our understanding of Supreme Court decision making. Specifically, we add to the growing literature that demonstrates oral arguments play an integral role in how the Court decides. While we know justices gather information during these proceedings (Johnson 2004), are influenced by the quality of arguments presented (Johnson, Spriggs, and Wahlbeck 2006), and engage in coalition formation (Johnson, Spriggs, and Wahlbeck 2007) with one another, the findings here add an emotional layer to this process. In other words, while justices gather information and seek answers that will help them decide close to their preferred outcome, they do so in a way that provides emotional clues as to how they may act when they finally vote on the merits and choose specific legal and policy outcomes.

But our findings go well beyond allowing us to simply make predictions about how cases will be decided. Rather, we believe these results can and should be integrated into larger analyses of elite

\footnotetext{
${ }^{19}$ Both differences between a liberal and conservative lower court decision are statistically significant at the 95\% level (two-tailed test).
}

decision making, especially on the Supreme Court. This is the case because emotion suggests intention, as we demonstrate here, but also suggests the level of commitment to that intention. Indeed, political psychologists have long argued emotion is one indicator of attitude importance (Miller and Peterson 2004; Petty and Krosnik 1995), which, in turn, is a strong predictor of future behavior and consistency of attitudes over time. Thus, observing emotions can tell us about justices' intentions in the present case as well as how susceptible their views may be to persuasion in future cases.

More broadly, we argue the emotions justices display as they grapple with the nation's most difficult legal issues may affect the manner in which they decide these issues or, alternatively, how they respond to the institutional constraints standing between them and their policy goals. That said, literature in judicial politics and elite decision making more generally, have paid little heed to attitude importance (or other indicators of attitude strength) because scholars have traditionally measured these concepts using experimental or survey data and have been unable to find an analogous measure using observational data. We believe analyzing the emotional content of justices' language at oral argument may provide such a measure, allowing scholars to gain leverage on these and other important questions for elite decision makers.

In the end, and most generally, we corroborate work that analyzes the role of emotion in our elected institutions. Indeed, existing analyses of the executive and legislative branches show the emotional nature of public statements is something scholars can and should understand. Here, we provide evidence that language Supreme Court justices' use at oral arguments may reveal their preferences in a particular case. This leads us to suspect (as have others in our field) that justices share much in common with political actors even though they are unelected and therefore largely unaccountable to the public. Ultimately, our analysis adds to what scholars have demonstrated of other institutional actors: the linguistic characteristics of words provide clues about the emotional nature of language used by political elites and their emotional nature, in turn, allows us to better understand their observed behavior.

\section{Acknowledgments}

A previous version of this paper was presented at the 2009 meeting of the Midwest Political Science 
Association. Data to replicate our findings are available at: http://www.polisci.umn.edu/ tjohnson/papers.php. Supplementary appendix materials can also be found at this URL as well as at http:// journals.cambridge.org/JOP. For providing helpful comments and feedback, we thank Peter Aurness, Amanda Bryan, Joanne Miller, Ryan Owens, Matt Roberts, Wendy Watson, Justin Wedeking, the participants of the American Politics Proseminar at the University of Minnesota and the American Politics Research Group at the University of North Carolina. Finally, Johnson and Goldman thank the National Science Foundation (IIS-0324992).

\section{References}

Austen-Smith, David. 1990. "Information Transmission in Debate." American Journal of Political Science 34 (February): $124-52$.

Ajzen, Icek. 1985. "From Intentions to Actions: A Theory of Planned Behavior." In Action-Control: From Cognition to Behavior, eds. Julius Kuhl and Jurgen Beckmann. Heidelberg, Ger.: Springer, 11-39.

Ajzen, Icek. 1996. "The Directive Influence of Attitudes on Behavior." In The Psychology of Action: Linking Cognition and Motivation to Behavior, eds. Peter Gollwittzer and John Bargh. New York: Guilford, 385-403.

Ajzen, Icek, and Martin Fishbein. 1980. Understanding Attitudes and Predicting Social Behavior. Englewood Cliffs, NJ: Prentice Hall.

Bagozzi, R., H. Baumgartner, R. Pieters, and M. Zeelenberg. 2000. "The Role of Emotions in Goal Directed Behavior." In The Why of Consumption: Contemporary Perspectives on Consumer Motives, Goals, and Desires, eds. S. Ratneshwar, David Glen Mick, and Cynthia Huffman. New York: Routledge, 36-58.

Berry, William D., Jacqueline H. R. DeMeritt, and Justin Esarey. 2010. "Testing for Interaction in Binary Logit and Probit Models: Is a Product Term Essential." American Journal of Political Science 54 (1): 248-66.

Collins, Paul. 2004. "Friends of the Court: Examining the Influence of Amicus Curiae Participation in U.S. Supreme Court Litigation." Law and Society Review 38 (4): 807-32.

Collins, Paul. 2008. Friends of the Supreme Court: Interest Groups and Judicial Decision Making. New York: Oxford University Press.

Diermeier, Daniel, and Timothy J. Fedderson. 2000. "Information and Congressional Hearings." American Journal of Political Science 44 (January): 51-65.

Dubois, Stephanie L. 1997. "Gender Differences in the Emotional Tone of Written Sexual Fantasies." Canadian Journal of Human Sexuality 6 (December): 307-15.

Eckert, Penelope. 1999. Language Variation as Social Practice: The Linguistic Construction of Identity in Belten High. New York: Blackwell.

Epstein, Lee, William M. Landes, and Richard A. Posner. Forthcoming. "Inferring the Winning Party in the Supreme Court from the Pattern of Questioning at Oral Argument." Journal of Legal Studies.
Fishbein, Martin, and Icek Ajzen. 1975. Belief, Attitude, Intention, and Behavior: An Introduction to Theory and Research. Reading, MA: Addison-Wesley.

Frijda, Nico. 1986. The Emotions. Cambridge: Cambridge University Press.

Greenhouse, Linda. 2004. "Press Room Predictions." Perspectives on Politics 2 (4) 781-84.

Greenhouse, Linda. 2008a. "Justices Indicate They May Uphold Voter ID Rules." New York Times, January 12, p. 14.

Greenhouse, Linda. 2008b. "Justices Indicate They May Uphold Voter ID Rules." New York Times, July 10, p. 1.

Hart, Roderick P. 2001. "Redeveloping Diction: Theoretical Considerations." In Theory, Method, and Practice in Computer Content Analysis, ed. Mark D. West. Westport, CT: Ablex, 43-60.

Johnson, Timothy R. 2004. Oral Arguments and Decision Making on the United States Supreme Court. Stony Brook: The State University of New York Press.

Johnson, Timothy R., Paul J. Wahlbeck, and James F. Spriggs II. 2006. "The Influence of Oral Arguments on the U.S. Supreme Court." American Political Science Review 100 (1): 99-113.

Johnson, Timothy R., Ryan C. Black, Jerry Goldman, and Sarah A. Treul. 2009. "Inquiring Minds Want to Know: Do Justices Tip Their Hands With Their Questions at Oral Arguments in the U.S. Supreme Court?" Washington University Journal of Law and Policy 29: 241-61.

Lacan, Jacques. 1968. The Language of the Self: The Function of Language in Psychoanalysis. Baltimore: Johns Hopkins Press.

Martin, Andrew D., and Kevin M. Quinn. 2002. "Dynamic Ideal Point Estimation via Markov Chain Monte Carlo for the U.S. Supreme Court, 1953-1999." Political Analysis 10: 134-53.

Martin, Andrew D., Kevin M. Quinn, Theodore W. Ruger, and Pauline T. Kim. 2004. "Competing Approaches to Predicting Supreme Court Decision Making." Perspectives on Politics 2 (4): 761-67.

Mayhew, David R. 1974. Congress: The Electoral Connection. New Haven, CT: Yale University Press.

McGuire, Kevin T., and Andrea McAtee. 2007. "Lawyers, Justices, and Issue Salience: When and How Do Legal Arguments Affect the U.S. Supreme Court." Law and Society Review 41: 259-78.

Miller, Joanne, and David Peterson. 2004. "Theoretical and Empirical Implications of Attitude Strength." The Journal of Politics 66 (3): 847-67.

Monroe, Burt L., Michael P. Colaresi, and Kevin M. Quinn. 2008. "Fightin' Words: Lexical Feature Selection and Evaluation for Identifying the Content of Political Conflict." Political Analysis 16: 372-403.

O'Brien, David M. 2008. Storm Center: The Supreme Court in American Politics. $8^{\text {th }}$ ed. W.W. Norton.

Pennebaker, James W., Matthias R. Mehl, and Kate G. Nieder hoffer. 2003. "Psychological Aspects of Natural Language Use: Our Words, Our Selves." Annual Review of Psychology 54: 547-77.

Petrone, Barbara, and Cynthia Whissell. 1988. "The Dictionary of Affect in Language as a Tool for the Assessment of Affective Tone in a Descriptive Task." Perceptual and Motor Skills 67 (3): 789-90.

Petty, Richard E., and Jon A. Krosnick. 1995. Attitude Strength Antecedents and Consequences. Mahwah, NJ: Lawrence Erlbaum Associates. 
Pieters, Rik, and W. Fred Raaij. 1988. "The Role of Affect in Economic Behavior." In Handbook of Economic Psychology, W. Fred Raaij, Gery M. van Veldhoven, and Karl-Erik Warneryd. Dordrecht, Neth.: Kluwer, 108-42.

Plutchik, Robert. 1994. The Psychology and Biology of Emotion. New York: Harper Collins.

Roberts, Jr. John G. 2005. "Oral Advocacy and the Reemergence of a Supreme Court Bar." Journal of Supreme Court History 30 (1): 68-81.

Russell, James A. 1978. "Evidence of Convergent Validity on the Dimensions of Affect." Journal of Personality and Social Psychology 36: 1152-68.

Robinson, W. Peter, and Howard Giles. 2001. The New Handbook of Language and Social Psychology. Chichester, UK: Wiley.

Schiffrin, Deborah. 1994. Approaches to Discourse. Cambridge, MA: Blackwell.

Segal, Jeffrey. 1988. "Amicus Curiae Briefs by the Solicitor General during the Warren and Burger Courts: A Research Note." Western Political Science Quarterly 41: 135-44.

Segal, Jeffrey A. and Albert Cover. 1989. "Ideological Values and Votes of Supreme Court Justices." American Political Science Review 83: 557-565.

Segal, Jeffrey A., and Harold J. Spaeth. 2002. The Supreme Court and the Attitudinal Model Revisited. Cambridge: Cambridge University Press.

Sheehan, Reginald, William Mishler, and Donald Songer. 1992. "Ideology, Status, and the Differential Success of Direct Parties before the Supreme Court." American Political Science Review 86 (June): 464-71.

Shullman, Sarah Levien. 2004. "The Illusion of Devil's Advocacy: How the Justices of the Supreme Court Foreshadow Their Decisions during Oral Argument." Journal of Appellate Practice and Process 6 (2).

Sigelman, Lee, Christopher Deering, and Burdett Loomis. 2000. "Wading Deep in the Words, Words, Words": Senatorial Rhetoric in the Johnson and Clinton Impeachment Trials." Paper presented at the annual meetings of the American Political Science Association, Chicago.

Sigelman, Lee, and Cynthia Whissell. 2002a. "Projecting Presidential Personas on the Radio: Addendum on the Bushes." Presidential Studies Quarterly 32: 572-76.

Sigelman, Lee, and Cynthia Whissell. 2002b. "The Great Communicator' and 'The Great Talker' on the Radio: Projecting Presidential Persona." Presidential Studies Quarterly 32 (1) 137-47.

Songer, Donald, and Reginald Sheehan. 1993. "Interest Group Success in the Courts: Amicus Participation in the Supreme Court." Political Research Quarterly 46: 339-54.
Tausczik, Yla R., and James W. Pennebaker. 2009. "The Psychological Meaning of Words: LIWC and Computerized Text Analysis Methods. Journal of Language and Social Psychology 29 (1): 24-54.

Wasby, Stephen L. Anthony D’Amato, and Rosemary Metrailer. 1976. "The Functions of Oral Arguments in the U.S. Supreme Court.” Quarterly Journal of Speech 62 (4): 410-22.

Whissell, Cynthia. 1989. "The Dictionary of Affect in Language." In Theory, Research, and Experience, eds. Robert Plutchik and Henry Kellerman. New York: Academic Press, 113-31.

Whissell, Cynthia. 1999. "Linguistic Complexity of Abstracts in Highly Cited Journals." Perceptual and Motor Skills 88: 76-86.

Whissell, Cynthia. 2001. "The Emotional Quality of William Blake's Poems: A Quantitative Comparison of Songs of Innocence to Sons of Experience." Perceptual and Motor Skills 92: 459-67.

Whissell, Cynthia and Lee Sigelman. 2001. "The Times and the Man as Predictors of Emotion and Style in the Inaugural Addresses of U.S. Presidents." Computers and the Humanities. 35: $255-272$.

Whissell, Cynthia, M. Fournier, R. Pelland, and K. Makarec. 1986. "The Dictionary of Affect in Language: Reliability, Validity, and Applications." Perceptual and Motor Skills 62: 875-88.

Wrightsman, Lawrence. 2008. Oral Arguments before the Supreme Court: An Empirical Approach. Oxford: Oxford University Press.

Zeelenberg, Marcel, Rob M. A. Neilssen, Seger M. Breugelmans, and Rik Pieters. 2008. "On Emotion Specificity in Decision Making: Why Feeling is for Doing." Judgment and Decision Making 3 (1): 18-27.

Ryan C. Black is Assistant Professor of Political Science at Michigan State University, East Lansing, Michigan, 48824.

Sarah A. Treul is a Lecturer at The University of North Carolina at Chapel Hill, Chapel Hill, NC 27599.

Timothy R. Johnson is Associate Professor of Political Science, University of Minnesota, Minneapolis, MN, 55455.

Jerry Goldman is Research Professor of Law, Chicago-Kent College of Law, Chicago, IL, 60661. 